\title{
EPIQR-TOBUS: a new generation of refurbishment decision aid methods
}

\author{
F. Flourentzos ${ }^{1}$, J.-L. Genre ${ }^{1}$, C.-A. Roulet $^{1}$ and T. Stöckli ${ }^{2}$ \\ ${ }^{1}$ Federal Institute of Technology - Lausanne (EPFL), Solar Energy and Building \\ Physics Laboratory (LESO-PB), LESO-EPFL, CH-1015 Lausanne, Switzerland \\ ${ }^{2}$ gs architekten ag, Hofstr. 31, CH-4127 Birsfelden
}

\section{Abstract}

In a large majority of European countries, the amount of maintenance and refurbishment works represents nearly $50 \%$ of the total amount spent in the building sector. New requirements are being added to the necessity of maintaining or re-establishing the building stock's usage value. They are linked to the determination to reduce energy consumption, pollutant emissions, work site wastes, to improve the Indoor Environment Quality (IEQ) and all the modern conveniences inside buildings. Two European projects, EPIQR (réf. nr.: JOR3-CT96-0044) and TOBUS (réf. nr.: JOR3-CT98-0235), developed in the III $^{\text {rd }}$ and IV ${ }^{\text {th }}$ framework programs put the foundations of a new generation of refurbishment decision aid tools. A structured diagnosis scheme covering the state of deterioration of the building elements, energy performance, indoor environment quality, functional obsolescence offer a new concept which helps architects and engineers to approach the building refurbishment with a global view of the whole process, to take informed decisions, to construct coherent refurbishment scenarii and calculate a reasonable investment budget in the very first stage of the refurbishment project. EPIQR project addresses residential buildings and it has been finished in 1998, TOBUS addresses office buildings and it is still in course. The support of these methods is a multimedia computer program. Several modules help the users to treat the data collected during a diagnosis survey, to set up refurbishment scenarii and calculate their cost or energy performance, and finally to visualise the results in a comprehensive way and to prepare quality reports. This paper presents the structure and the main features of the method and software.

Keywords: maintenance, refurbishment, decision aid tools 


\section{EPIQR-TOBUS: eine neue Generation von Entscheidungshilfen für das Bauinstandsetzen}

\section{Zusammenfassung}

In den meisten europäischen Ländern entfält heute fust die Hälfte der Ausgaben im Bauwesen auf den Unterhalt und das Instandsetzen. Neue Anforderungen kommen zur Notwendigkeit des Unterhaltes und des Wiederherstellens des Wertes der Bausubstanz hinzu. Diese Anforderungen hängen einerseits mit dem Ziel, den Energieverbrauch, den Schadstoffausstoss und Abfälle auf der Baustelle zu vermindern, und andererseits mit dem Verbessern der Lebensqualität im Gebäude (IEQ) und allen modernen Bequemlichkeiten (Wohnkomfort), zusammen. Im Rahmen von zwei europäischen Projekten EPIQR (réf. nr.: JOR3-CT96-0044) und TOBUS (réf. nr.: JOR3-CT98-0235) w'urde im III. und IV. Rahmenprogramm die Grundlage für eine neue Generation von Entscheidungshilfen für das Bauinstandsetzen gelegt. Ein strukturiertes Diagnosesystem, das den Schadenszustand der. einzelnen Baukomponenten, den Energieverbrauch und die Behaglichkeit im Inneren sowie veraltete Systeme umfasst, bietet ein neues Konzept, das Architekten und Ingenieuren hilft, das Bauinstandsetzen mit einer globalen Betrachtung des gesamten Prozesses anzugehen und dabei wissensorientierte Entscheidungen zu treffen, kohärente Szenarien des Bauinstandsetzens zu entwickeln und bereits in der Beginnphase eine vernünftige Kostenrechnung für eine notwendige Instandsetzung aufzustellen. Das EPIQR Projekt betraf Wohngebäude. und es wurde 1998 abgeschlossen. TOBUS wird für Bürogebäude entwickelt und ist noch in Arbeit. Was diese Programme bieten, ist ein multimediales Rechenprogramm. Mehrere Module helfen dem Benutzer, die Daten einer vorausgegangenen Bauschadenaufnahme auszuw'erten und auf dieser Basis Inszenarien fül das Baminstandsetzen zu erstellen und deven Kosten und Energiebilanz zu berechnen. Schliesslich können die Ergebnisse umfassend visualisiert werden, und es können Qualitätsberichte vorbereitet w'erden. In diesem Beitrag werden der Aufhau und n'esentliche Eigenschaften der Methode und der entwickelten Software vorgestellt.

Stichwörter: Bauunterhalt, Instandsetzen. Entscheidungshilfen 


\section{Introduction}

The EPIQR method is a decision aid tool for residential building refurbishment. TOBUS takes all the EPIQR features and develops new ones specific to office buildings. These methods help the expert to establish a structured building diagnosis covering building deterioration, energy performance, indoor environment quality, and compliance with standards and regulations. The expert can build various refurbishment scenarii and calculate for each of them the refurbishment cost. He can calculate the energy balance of the existing situation and identify the energy saving potential for retrofit actions. A special module helps the expert to perform a cost analysis and personalises the method costs. In office buildings technical installations and services have equal or more importance than deterioration. Functional obsolescence and energy savings related to services as well as indoor environment quality specific to office activity are new features developed in TOBUS.

EPIQR and TOBUS is the result of a European research projects in the IIIrd and IVth framework programs. A multidisciplinary team with research institutes and private consultants from Switzerland, Germany, France, The Netherlands, Denmark, United Kingdom and Greece participated in the projects, bringing their expertise in all the domains touching refurbishment and giving a global approach to the method. In addition to building deterioration and functional obsolescence, energy savings and occupant comfort got a central place in the very early stage of the decision process.

The interface of the software is programmed in Microsoft Visual Basic 5 and the databases in Microsoft Access 97. The program runs on a standard PC with Windows $95 / \mathrm{NT} 4$. The EPIQR software is now available on the Swiss, French, German, Danish and Greek markets and it is also translated in Italian and English. The TOBUS software will be compatible with EPIQR. The user will use the one or the other depending wether the study is for a residential or office building.

\section{Software Modules}

\subsection{General}

Different modules allow the user to work on a project to the degree of detail he wishes according to the available budget for the study. Within four hours, an expert user can give a first rough estimate of the global refurbishment cost, allowing three hours for the visit and one hour for data handling. A complete project with a description of the current state of each building element, functional obsolescence, an energy balance, a report on the indoor environment quality and two or three refurbishment scenarii may take two to four working days depending on the complexity of the project. 


\subsection{Building Deterioration State}

Each building is decomposed into elements. EPIQR has 50 elements while the TOBUS element list is under construction. Examples of elements are windows. façade finish, boiler. electrical installation etc. [1]. For each building element, different types may exist. The user chooses the type that corresponds to the actual building and decides which of the deterioration codes a, b. c, or d described by the method, best fits the observed state of the building element. In addition to the detailed description, one or more pictures illustrate the four possible deterioration states. A total of about 500 photos and sketches help the user to decide on the correct deterioration code (Figure 1).

Upgrading retrofit work is described separately in order to distinguish work necessary to bring the building element back to current standards from work that adds value to the building.

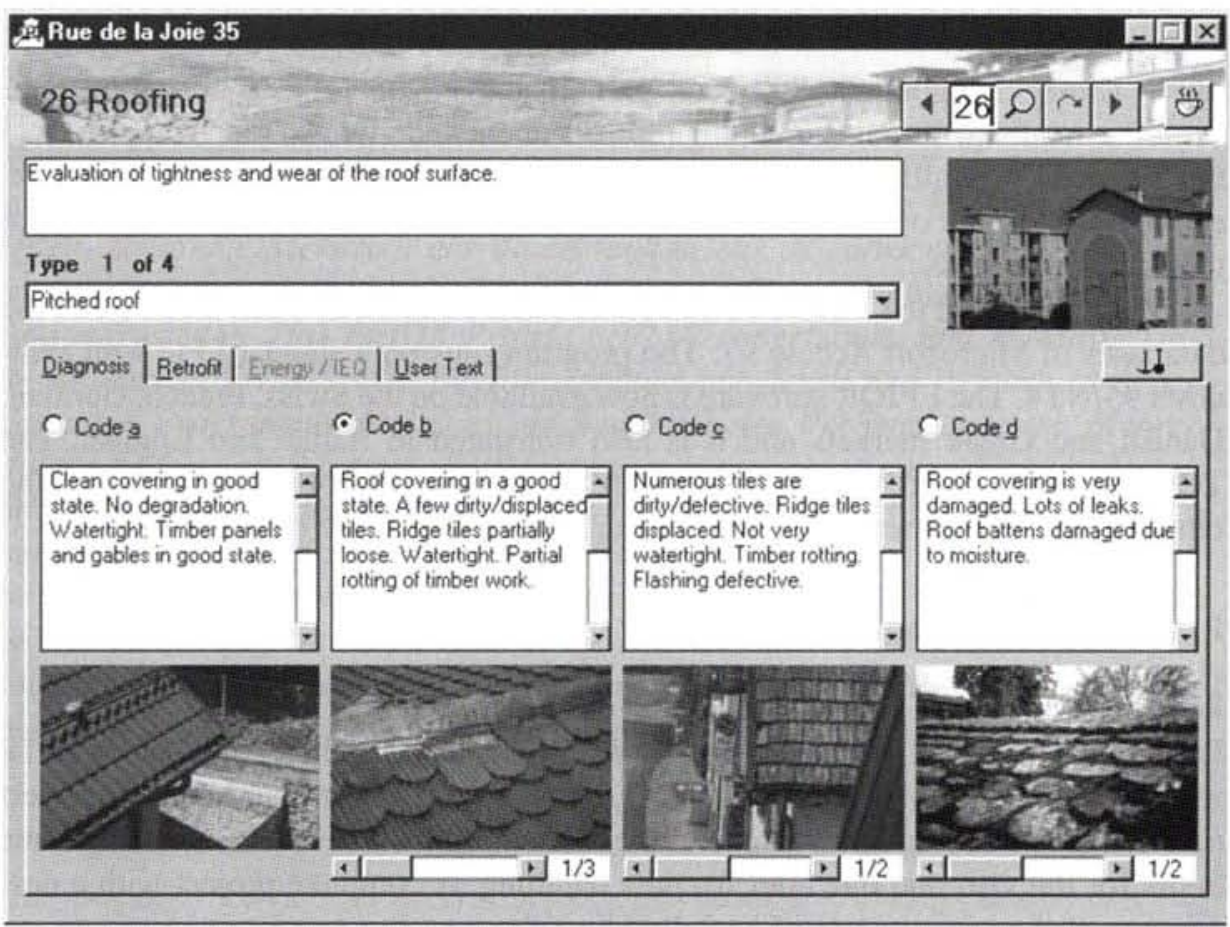

Figure 1: The users have to decide to which deterioration code the observed element corresponds. Several pictures illustrate the codes and ease the decision-making. 


\subsection{Building Characteristics}

Based on the current state of the building elements the user can select from the action database the appropriate refurbishment intervention. The program calculates the cost of each intervention using only few (7-10) dimensional coefficients. These are façade areas, built area, area of foundations, lot area, number of apartments, number of stories and number of staircases. The program will adjust the refurbishment cost according to building dimensional coefficients and building complexity coefficients defined by the user. A price update index adjusts the cost taking into account price variation over time (every country has an institution giving the current price index).

\subsection{Heating/Cooling Energy Requirement and Energy Saving Potentail}

Energy bills show the current state of the building energy consumption. This state is compared to the standard and best practice values of the country to illustrate the saving potential.

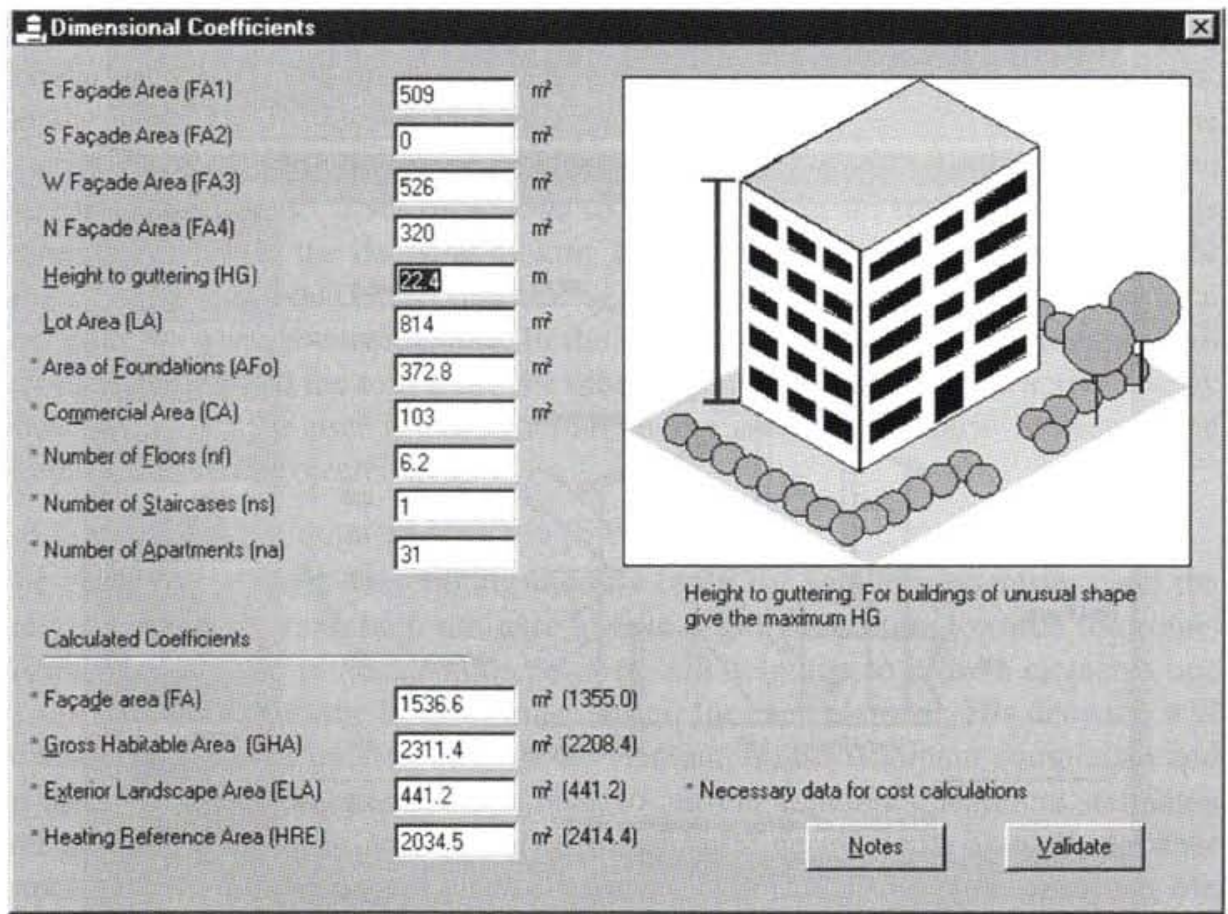

Figure 2: Building dimensional coefficients for the calculation of the refurbishment cost and building complexity coefficients for the adaptation of the database costs to the particular project. 


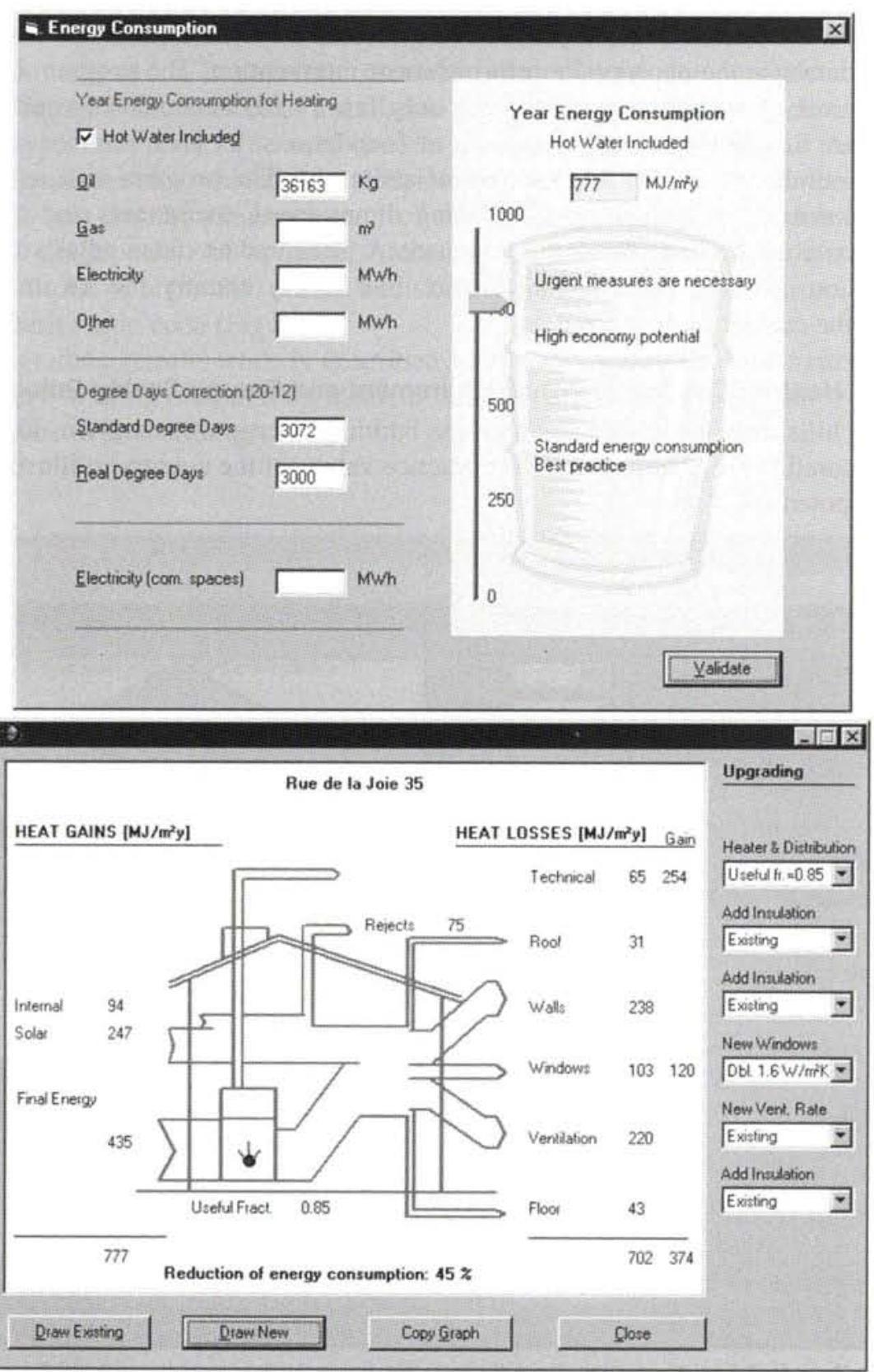

Figure 3: The current energy consumption indicates the global energy saving potential (above). The energy balance heating calculation (below) shows the potential of some actions separately. 
A simplified energy balance calculation based on EN-832 [2] shows the heat loss distribution and guides the user to retrofit measures with a higher energy saving potential. For southern countries the energy saving potential for cooling is also evaluated

\subsection{Occupants and Indoor Environment Quality [3]}

Before the building audit, a questionnaire is distributed to the occupants with questions on the indoor environment and apartment facilities quality. This questionaire helps the surveyor to identify hidden problems in the building or to support his arguments in refurbishment strategy discussions with the owner. The software performs a statistical treatment of the questionnaire and relates complaints with refurbishment work and energy retrofit measures. If for example the occupants observe rusty or dirty hot water, the software will suggest replacement of the hot water distribution system and if they feel cold draughts or condensation on the windows, it will suggest replacement of element 39 (windows).

\subsection{Building a Refurbishment Scenario}

\subsubsection{Decide a refurbishment strategy (Step 1)}

A radar graph summarises the building deterioration state of the building elements. On the same graph the user can visualise the refurbishment cost instead of the deterioration state and identify the most expensive actions. The graph is active and the user can de-select a set of actions to see the effect on the total cost. This is extremely useful in the decision making process when the investment budget for renovation is limited. Deselecting all façade elements in this example, the total cost does not change considerably. In the cost graph, we can see that for this project the kitchens and the toilets are the most expensive elements. The active energy flowchart assists the user to construct an energy coherent scenario by testing the effect of different projected actions.

\subsubsection{Elaborate a detailed scenario (Step 2)}

The energy flow chart, the cooling module (only for southern countries) and the deterioration/cost graph help the user to take a global attitude towards the refurbishment of a given project. Another screen will help him to browse elements one by one and decide on the level of intervention for each element. His decision will be based on the deterioration state of the element, on the occupant complaints and on the cost of bringing the element back to current standards. National standards and guidelines affect refurbishment of many building elements as well. Another important decision parameter made available by the software is the remaining life span of the building elements [4]. All this information should help the user to take a more coherent decision. The user can browse one by one through the elements 

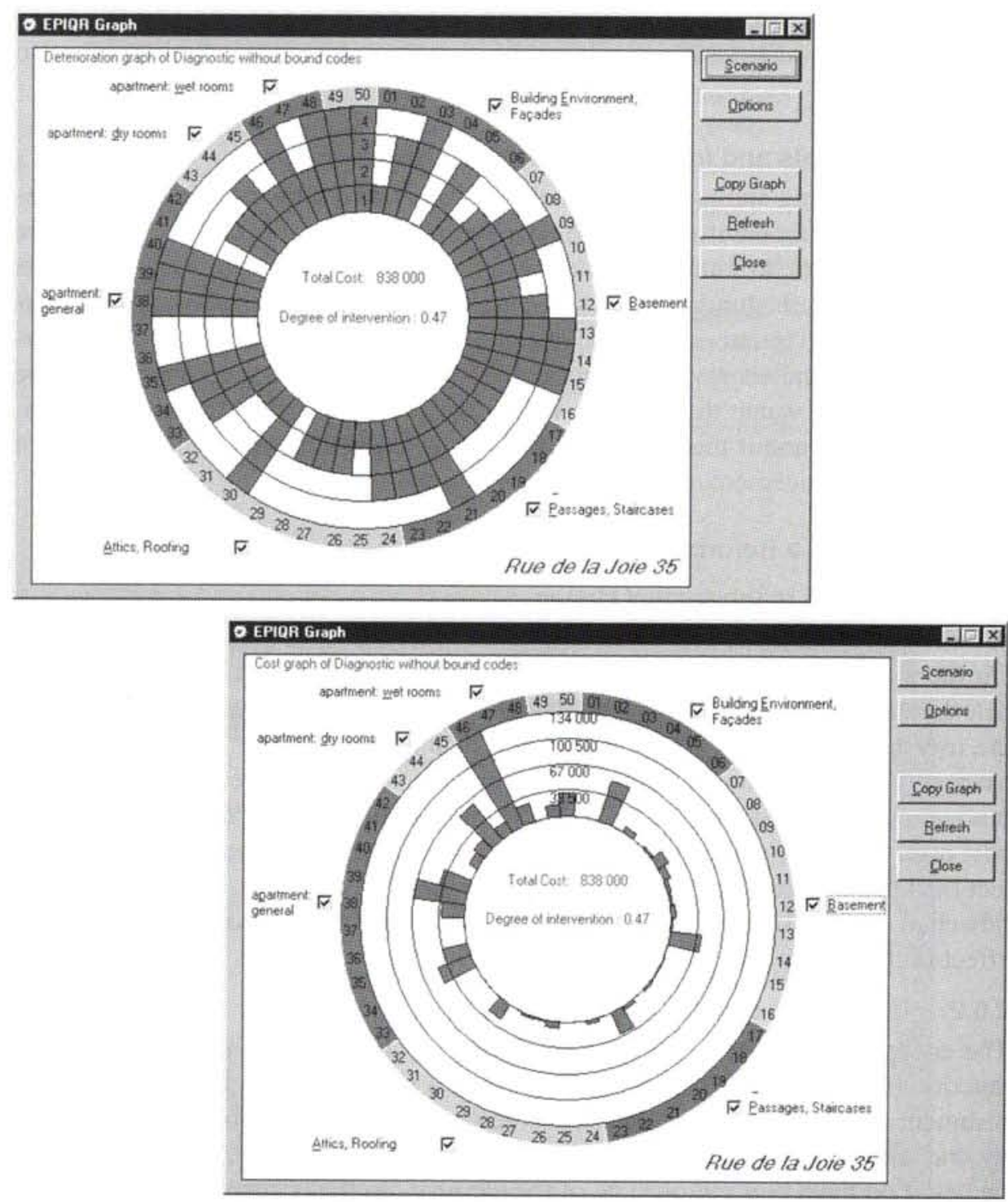

Figure 4: The active graph shows either the element deterioration state, the bars on the upper picture, or the element refurbishment cost, the bars on the lower picture. The user can project different scenarios by deselecting one or several element groups (the sectors on the circle circumference). The degree of intervention is the ratio of the actual cost to the cost if all the elements where deteriorated to code d. 
and by deciding on the level of intervention for each of them the total cost of the scenario is updated.

\subsection{Cost Analysis}

The program calculates the scenario cost element by element. This first rough estimate helps the refurbishment expert to converse with the owner to decide upon the retrofit strategy taking into account budget limitations. This interaction could be iterative until the two converge on the most convenient scenario. At this stage the user must perform a more accurate cost analysis. For each element the program gives a more detailed description of work and costs. The user can modify the calculated cost and give his own estimate. The detailed descriptions of the actions to be undertaken are such that they can be classified either according to an element classification method or a trade classification method [5, 6]. The Swiss building cost classification method $\mathrm{BCC}$ is already implemented in the program and the user can, for example, group all masonry work together, carpentry in another group, sanitary in another etc. It is possible to also integrate into the software different national classification methods.

\section{Conclusions}

The EPIQR and TOBUS methods are neither a simulation program nor an expert system. It is a support that makes decision making easier, more rational and coherent. The software does not decide for the user but gives him enough information elements to take an informed decision. It combines information from the audit, from the cost and deterioration database, from the picture database and from energy calculations, to assist the decision actors from the first moment of the project until a decision is taken on the refurbishment scenario. This combination brings forward energy and indoor environment quality issues into the first stage of the decision making process, when there are still many possibilities for open alternatives. In practice these issues are usually ignored at the first stages of the project and only the physical state of the building and the cost are considered. Often energy, when considered at all, comes in during the detailed project phase only and then it might be too late for variations. As soon as the refurbishment budget has been decided on, the margin for modifying the initial project is too narrow.

Using computers in the decision making process allows almost immediate availability of data that would take considerable time to calculate manually. In this new environment, the expert can test several combinations and scenarii within a reasonable time, which opens new perspectives.

Since the software does not decide for the user but assists him to decide, it is necessary that the user has some level of expertise on building refurbishment. However, it does not require any advanced computer expertise. Building experts 
with little experience in building physics for energy savings can also take advantage of the software.

The user-friendly interface and its multimedia features make the software an excellent pedagogical instrument to teach building refurbishment. The EPIQR software is used with much success at the Department of Architecture of the Federal Institute of Technology in Lausanne.

\section{References}

1. J.-L. Genre, F. Flourentzou, A. Faist, EPIQR a new refurbishment concept. Second European Conference: Energy Performance and Indoor Climate in Buildings (EPIC), Lyon November, 19-21 (1998)

2. EN 832: 1998, Thermal Performance of Buildings - Calculation of energy use for heating - Residential Buildings, CEN, Brussels, Belgium.

3. Philomena Bluyssen, EPIQR: IEQ part of EPIQR, TNO report 98-BBI-R0844, Delft (1998)

4. Flourentzou F., Genre J-L, Faist A., MEDIC: prediction method of probable deterioration scenarios and refurbishment investment budgets, EPIC conference, Lyon (1998)

5. Swiss Standard SN 506 502, CCE - Cost Classification by Elements, CRB, Zurich (1995)

6. Swiss Standard SN 506 502, BCC - Cost Classification by Elements, CRB. Zurich (1997) 


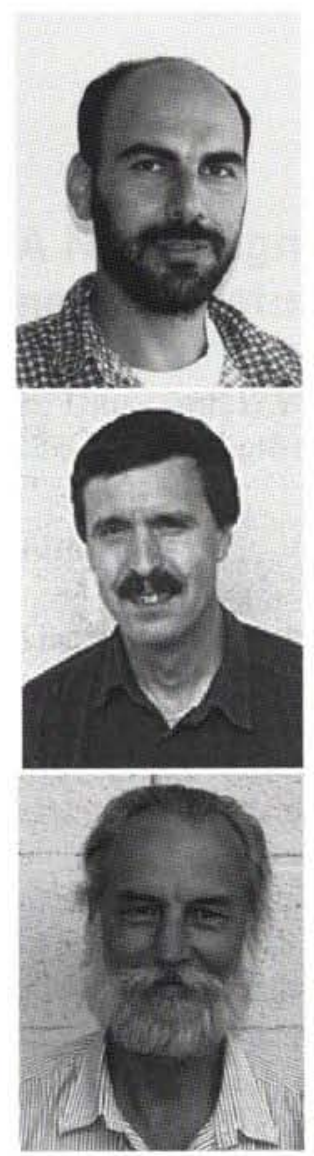

F. Flourentzos: 1981-1984: Diploma of Technician Engineer - "Higher Technical Institute", Chypre. 1992-1994: Diplôme d'Ingénieur, opt. Energétique Industrielle - Ecole des Mines de Douai. 1993-1994: DEA en Energétique et Mécanique de Fluides - Université de Valenciennes. 1996-2000: DES en études du développement (sciences sociales), Université de Genève. 1994-2000: EPFL, LABORATOIRE D'ENERGIE SOLAIRE. (6 ans) Assistant.

J.-J. Genre; 1983 Diplôme d'architecte DPLG, Marseille, sujet: Habitat en tissu ancien à Aubagne, Depuis janvier 1996: Employé au LESO du Département d'Architecture de l'EPFL (à mi-temps à partir de Janvier 1996 et à $80 \%$ depuis Avril 1998) en qualité de collaborateur scientifique.

C.-A. Roulet, Ecole Polytechnique de l'Université de Lausanne EPUL), diplôme d'ingénieur physicien en 1964. Thèse de doctorat en sciences EPFL en février 1973. Adjoint scientifique au Groupe de Recherches sur l'Énergie Solaire, devenu Laboratoire d'énergie solaire et de physique du bâtiment à l'EPFL dès avril 1982. Travaux sur les méthodes de mesure in situ concernant l'énergie dans le bâtiment et sur la modélisation du comportement thermique des bâtiments. Actuellement, dirige des recherches sur les stratégies de rénovation et sur la qualité de l'environnement intérieur dans les bâtiments. Privatdocent à l'EPFL. 
